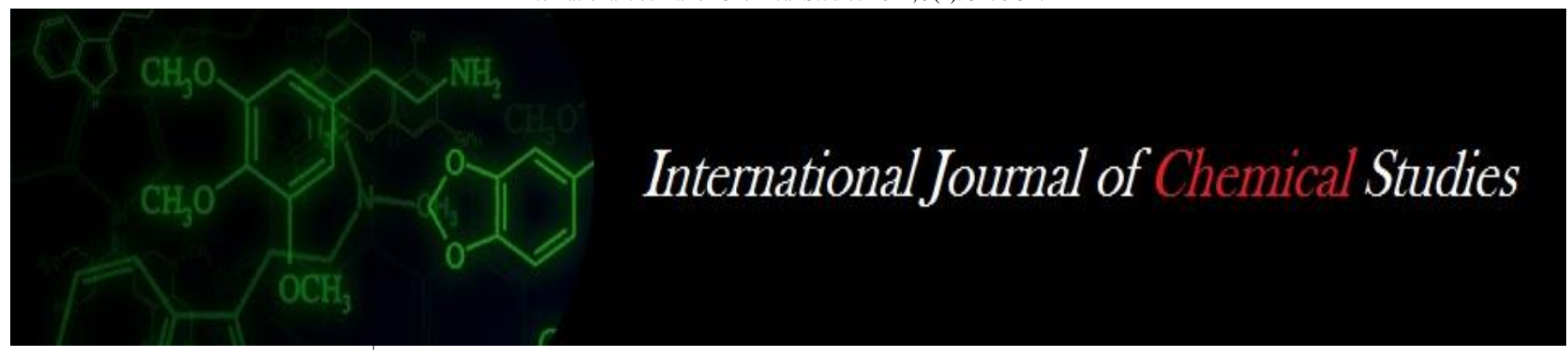

P-ISSN: 2349-8528

E-ISSN: 2321-4902

www.chemijournal.com

IJCS 2021; 9(1): 3270-3272

(C) 2021 IJCS

Received: 15-10-2020

Accepted: 30-11-2020

Manendra Kumar

Department of Crop Physiology,

Acharya Narendra Deva University

of Agriculture and Technology,

Kumarganj, Ayodhya, Uttar

Pradesh, India

Pradip Kumar Sain

Department of Crop Physiology,

Acharya Narendra Deva University

of Agriculture and Technology,

Kumarganj, Ayodhya, Uttar

Pradesh, India

RK Yadav

Department of Crop Physiology, Acharya Narendra Deva University of Agriculture and Technology, Kumarganj, Ayodhya, Uttar Pradesh, India

Alok Kumar Singh

Department of Crop Physiology, Acharya Narendra Deva University of Agriculture and Technology, Kumarganj, Ayodhya, Uttar Pradesh, India

Sumant Pratap Singh

Department of Plant Molecula Biology \& Genetic Engineering, Acharya Narendra Deva University of Agriculture and Technology, Kumarganj, Ayodhya, Uttar Pradesh. India

Brijesh Kumar

Department of Agriculture

Biochemistry, Acharya Narendra

Deva University of Agriculture and

Technology, Kumarganj, Ayodhya,

Uttar Pradesh, India

RN Kewat

Department of Agriculture Biochemistry, Acharya Narendra Deva University of Agriculture and Technology, Kumarganj, Ayodhya, Uttar Pradesh, India

Corresponding Author: Pradip Kumar Saini Department of Crop Physiology, Acharya Narendra Deva University of Agriculture and Technology, Kumarganj, Ayodhya, Uttar Pradesh, India

\section{Effect of foliar application of different nutrients on biochemical changes of wheat (Triticum aestivum $\mathbf{L}$.) under sodic soil}

\author{
Manendra Kumar, Pradip Kumar Saini, RK Yadav, Alok Kumar Singh, \\ Sumant Pratap Singh, Brijesh Kumar and RN Kewat
}

DOI: https://doi.org/10.22271/chemi.2021.v9.i1at.11737

\begin{abstract}
The present investigation entitled "Effect of foliar application of different nutrients on biochemical changes of wheat, under sodic soil" was carried out at main experiment station (MES) of Acharya Narendra Dev University of Agriculture \& Technology, Narendra Nagar, Kumarganj, Ayodhya (U.P). During Rabi season 2017-18. The experiment was laid in field condition with randomized block design and three replications\& variety NW-1014. Seven treatments comprised of five different nutrients as zinc sulphate $(0.5 \%)$ and $(0.7 \%)$, boric acid $(0.2 \%)$ and $(0.4 \%)$ and potassium nitrate $(0.1 \%)$ and $(0.3 \%)$ applied as foliar application at 35 DAS of crop growth. A controlled set was also maintained. The observations were recorded parameters biochemical changes at 40,60 and 90 DAS. All the foliar application of nutrients increased the growth characters and biochemical changes superior over control. Total chlorophyll content and total carbohydrate was found significantly superior with foliar application of $0.7 \%$ zinc sulphate at all the stages of crop over control.
\end{abstract}

Keywords: Wheat, chlorophyll, carbohydrate, zinc sulphate, boric acid

\section{Introduction}

Wheat (Triticum aestivum L.) is a staple food of the world and belongs to family Poaceae (Gramineae). It is most important staple food of about two billion people (36\% of the World population). About $55 \%$ of the world population depends on wheat for intake of about $20 \%$ of food calories. Wheat is self-pollinated crop and it has been described as the 'King of cereals'. It is the world's most widely cultivated food crop and is primarily grown in temperate regions and also at higher altitude under tropical climatic areas in winter season. Wheat is the single most important cereal crop that has been considered as integral component of the food security system of the several nations. It is grown in the world with an area of 221.60 million hectare, production of 728.3 million tonnes with productivity of 3.3 tonnes per hectare (Anonymous $2015)^{[1]}$. In India, it is grown in an area of 30.47 million hectare, production 95.85 million tone's with a productivity of 3.15 tonnes per hectare. Uttar Pradesh having first rank in respect of both area (9.95 million hectare) and production (30.24 million tone's) with a productivity of 3.10 tone's per hectare in 2015 (Anonymous 2015) ${ }^{[1]}$. The fast growing population of our country makes it imperative to enhance wheat production accordingly. Wheat is cultivated on an area of 8693 thousand hectares with a total production of 25,286 thousand tonnes during year 2012-13 (GOP, 2012-13). The major fraction of potash fertilizer directly applied to soil gets fixed by the clay fraction and becomes unavailable to crop plants (Ali et al., 2010) ${ }^{[2]}$. The available zinc in Indian soil ranges between 0.08-20.5 ppm. Application of zinc has been found to boost the growth and yield of crops to a great extent. Zinc deficiency includes rosetting and poor tillering leading to decreased productivity in crop plants. Since zinc is cofactor of carbonic anhydrase and aldolase, therefore, it may adversely affect enzyme activities and carries corresponding metabolic reactions when zinc is deficient in soil. Zinc is also involved in synthesis of protein, tryptophan (amino acid). Superoxide dismutase (SOD) activity is much lower but can be restored in vitro by resupplying zinc to the assay medium, indicating that the zinc is an essential structural components for normal functioning of superoxide dismutase enzyme. In zinc stressed plants, protein synthesis is inhibited and amino 
acids are accumulated up to inhibitory level (Cakmak \& Marschner, 2003) [4]. Zinc deficiency also affects the metabolism of phosphorus, nitrogen, carbohydrate and nucleic acid (Cakmak, 1988) [5]. Potassium nitrate an ionic salt of potassium ions $\mathrm{K}^{+}$and nitrate ions $\mathrm{NO}_{3}^{-}$, and is therefore an alkali metal nitrate. It occurs as a mineral nutrient and is a natural solid source of nitrogen. Potassium nitrate is one of several nitrogen-containing compounds collectively referred to as saltpeter or saltpetre. Major uses of potassium nitrate are in fertilizers, tree stump removal, rocket propellants and fireworks. It is one of the major constituents of gunpowder (black powder) and has been used since the Middle Ages as a food preservative. Sodic soil are widespread in the world and in India. It occurs mainly in Indo-Gangetic alluvial plains, where it is estimated to cover about $2.8 \mathrm{mha}$. In India, salt affected soils are spread $7.0 \mathrm{mha}$, of which, $1 * 29$ mha exists in U.P. alone. Zinc is the last element in the first transition series to be required by plants. The normal concentration of zinc in plants ranges from 25$100 \mathrm{ppm}$ on dry matter basis. Corn and beans are particularly sensitive to zinc deficiency. Zinc deficiency can often identified by distinctive visual symptoms which occur most frequently in the leaves.

\section{Materials and Methods}

The present experiment was conducted during Rabi season of 2017-18 at the Main Experimental Station (MES), of Acharya Narendra Deva University of Agriculture and Technology, Kumarganj, Ayodhya (U.P.). Experimental site is situated 42 $\mathrm{km}$ away from Ayodhya on Ayodhya-Raibarreilly road between latitude of $24.47{ }^{0}$ north and longitude of $82.12^{\circ}$ and $83.98{ }^{0}$ east on an elevation of 113 meters in the gangetic alluvium of eastern Uttar Pradesh. The experiment was laid in field condition with randomized block design and three replications \& variety NW-1014. Seven treatments comprised of five different nutrients as zinc sulphate $(0.5 \%)$ and $(0.7 \%)$, boric acid $(0.2 \%)$ and $(0.4 \%)$ and potassium nitrate $(0.1 \%)$ and $(0.3 \%)$ applied as foliar application at 35 DAS of crop growth. A controlled set was also maintained. The observations were recorded parameters biochemical changes at, 40, 60 and 90 DAS. All the foliar application of nutrients increased the growth characters and biochemical changes superior over control. The analysis of variance for the design of experiment was carried out according to the procedure outlined by Fisher and Yates (1949).

\section{Result and Discussion}

Total chlorophyll content in leaves (SPAD Value)

The mean data pertaining to total chlorophyll content in leaves, under various nutrient treatments are presented in Table -1. The total chlorophyll content in green leaves increased up to 40, 60, DAS and declined at 90 DAS. Maximum increase in total chlorophyll content was obtained with foliar application of $-0.7 \% \mathrm{ZnSO}_{4}(11.55,12.72$ and 10.43 SPAD Value) at 40, 60 and 90 DAS followed by foliar application of $0.3 \% \mathrm{KNO}_{3}(11.43,12.65$ and $10.24 \mathrm{SPAD}$ Value) at 40, 60 and 90 DAS, respectively, over rest of treatments. However, minimum total chlorophyll content was recorded with $0.2 \%$ boric acid $(10.62,12.31$ and 9.21 SPAD Value) at 40,60 and 90 DAS, respectively against control.

Table 1: Effect of foliar application on total chlorophyll (SPAD Value) at various growth stages of wheat varieties under sodic soil

\begin{tabular}{|c|c|c|c|}
\hline \multirow{2}{*}{ Treatment } & \multicolumn{3}{|c|}{ Total Chlorophyll content in leaves } \\
\cline { 2 - 4 } & 40 DAS & 60 DAS & 90 DAS \\
\hline $\mathrm{T}_{1}-$ Control & 10.35 & 12.04 & 8.71 \\
\hline $\mathrm{T}_{2}-0.2 \%$ Boric acid & 10.62 & 12.31 & 9.21 \\
\hline $\mathrm{T}_{3}-0.4 \%$ Boric acid & 11.42 & 12.51 & 10.21 \\
\hline $\mathrm{T}_{4}-0.5 \% \mathrm{ZnSO}_{4}$ & 11.12 & 12.42 & 9.63 \\
\hline $\mathrm{T}_{5}-0.7 \% \mathrm{ZnSO}_{4}$ & 11.55 & 12.72 & 10.43 \\
\hline $\mathrm{T}_{6}-0.1 \% \mathrm{KNO}_{3}$ & 10.72 & 12.32 & 9.47 \\
\hline $\mathrm{T}_{7}-0.3 \% \mathrm{KNO}_{3}$ & 11.43 & 12.65 & 10.24 \\
\hline $\mathrm{S.Em} \pm$ & 0.40 & 0.45 & 0.36 \\
\hline $\mathrm{CD}$ at $5 \%$ & 1.23 & 1.38 & 1.10 \\
\hline
\end{tabular}

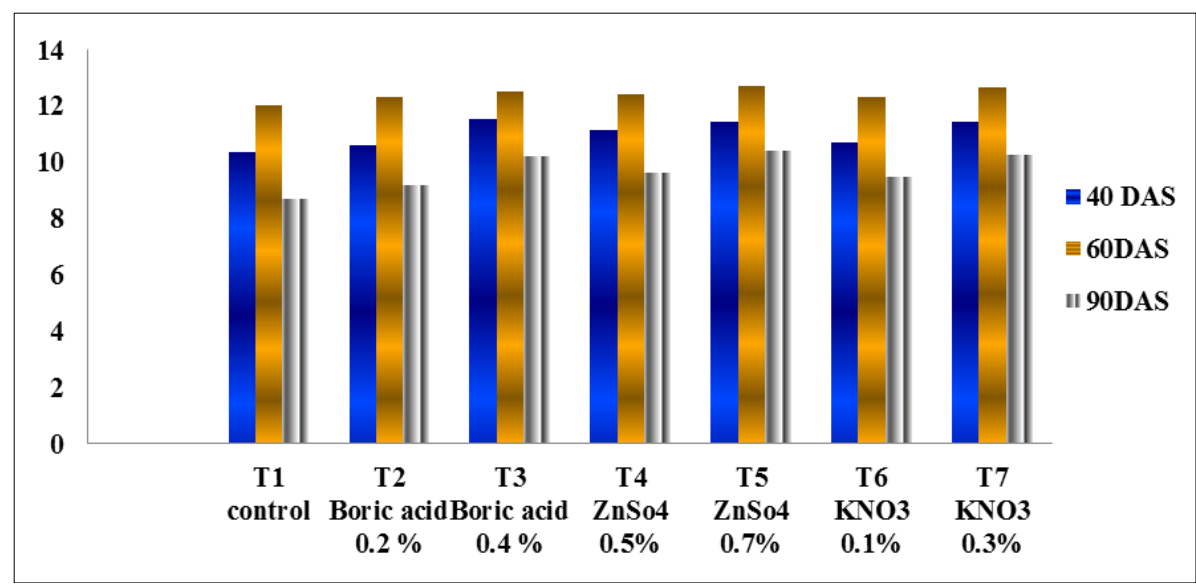

Fig 1: Effect of foliar application on total chlorophyll (SPAD Value) wheat under sodic soil

\section{Carbohydrate}

The mean data pertaining to total carbohydrate content in dry leaves under various nutrient treatments are presented in Table-2. All the treatments showed increase in total carbohydrate content, at all the stages of observation over the control. However, maximum increase in total carbohydrate content was recorded with foliar application of $0.7 \% \mathrm{ZnSO}_{4}$ (208.50, 342.80 and $139.50 \mathrm{mg} \mathrm{g}^{-1}$ dry weight) at 40, 60 and 
90 DAS followed by foliar application of $0.3 \% \mathrm{KNO}_{3}$ (204.20, 282.60 and $135.80 \mathrm{mg} \mathrm{g}^{-1}$ dry weight) at 40, 60 and 90 DAS, respectively, over rest of the treatments. Minimum carbohydrate content in dry leaves were recorded with foliar application of $0.2 \%$ boric acid $(188.70,232.20$ and $126.40 \mathrm{mg}$ $\mathrm{g}^{-1}$ dry weight) at 40, 60 and 90 DAS, respectively, over control.

Table 2: Effect of foliar application on carbohydrate ( $\mathrm{mg} \mathrm{g}^{-1}$ dry weight) of wheat varieties under sodic soil

\begin{tabular}{|c|c|c|c|}
\hline \multirow{2}{*}{ Treatment } & \multicolumn{3}{|c|}{ Total Carbohydrate content } \\
\cline { 2 - 4 } & 40 DAS & 60 DAS & 90 DAS \\
\hline $\mathrm{T}_{1}-$ Control & 185.80 & 230.50 & 110.20 \\
\hline $\mathrm{T}_{2}-0.2 \%$ Boric acid & 188.70 & 232.20 & 126.40 \\
\hline $\mathrm{T}_{3}-0.4 \%$ Boric acid & 203.80 & 236.60 & 135.20 \\
\hline $\mathrm{T}_{4}-0.5 \% \mathrm{ZnSO}_{4}$ & 190.40 & 235.50 & 128.70 \\
\hline $\mathrm{T}_{5}-0.7 \% \mathrm{ZnSO}_{4}$ & 208.50 & 342.80 & 139.50 \\
\hline $\mathrm{T}_{6}-0.1 \% \mathrm{KNO}_{3}$ & 202.60 & 267.50 & 129.30 \\
\hline $\mathrm{T}_{7}-0.3 \% \mathrm{KNO}_{3}$ & 204.20 & 282.60 & 135.80 \\
\hline $\mathrm{S} . \mathrm{Em} \pm$ & 7.25 & 10.87 & 4.78 \\
\hline $\mathrm{CD}$ at $5 \%$ & 22.33 & 33.50 & 14.72 \\
\hline
\end{tabular}

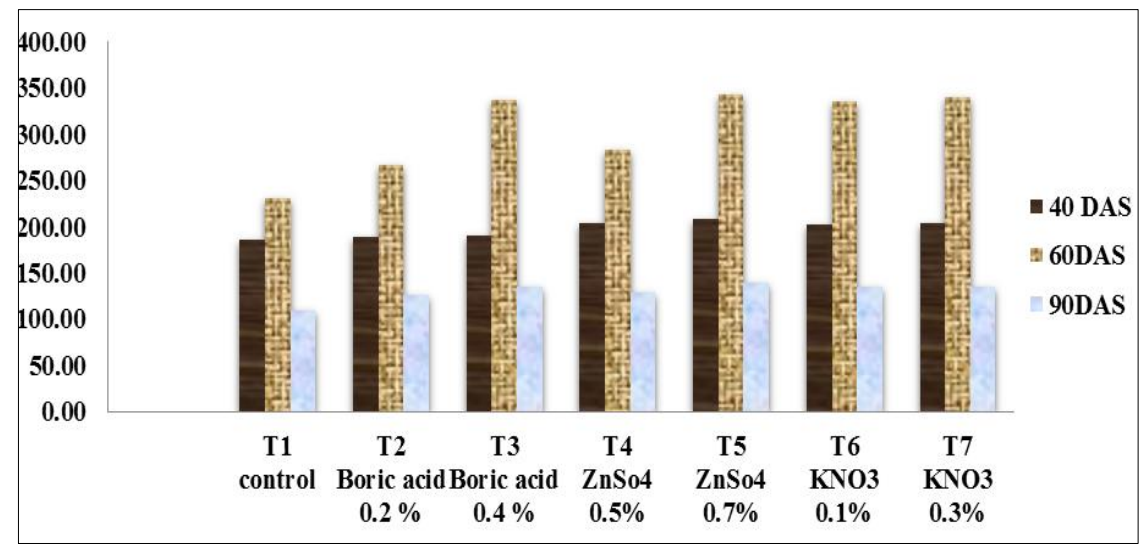

Fig 2: Effect of foliar application on carbohydrate ( $\mathrm{mg} \mathrm{g}^{-1}$ dry weight) wheat under sodic soil

\section{Conclusion}

All the treatment increased chlorophyll content was estimated in at all the stage of growth but maximum chlorophyll content was recorded in foliar application of $0.7 \%$ zinc sulphate, $(11.55,12.72$, and 10.43 SPAD Value) at 40, 60, and 90 DAS, respectively followed by foliar application of $0.3 \%$ potassium nitrate and $0.2 \%$ boric acid over the treatment during observation. Higher carbohydrate was analysed with foliar application of $0.7 \%$ zinc sulphate (208.50, 342.80 and 139.50 $\mathrm{mg} \mathrm{g}^{-1}$ ) at 40, 60 and 90 DAS respectively, followed by foliar application of $0.3 \%$ potassium nitrate and $0.2 \%$ boric acid over of the rest treatments including control. Biochemical parameters improved with use of nutrients $\left(\mathrm{ZnSo}_{4}, \mathrm{KNO}_{3}\right.$ and boric acid) possibly through maintain higher total soluble carbohydrate and chlorophyll.

\section{Reference}

1. Anonymous. Directorate of Economics \& Statistics, Department of Agriculture \& Cooperation 2015-16.

2. Ali MA, Muhammad Aslam, Zafar Abbas. Response of wheat to different doses of Znso4 under thal desert environment. Pak. J Bot 2010;42(6):4079-4085.

3. Bharti Jai, Malik CP. Evaluation of biochemical parameters in nitrate-hardened seeds of Indian mustard subjected to salt stress. J of Oil. Brassica 2013;4(1):1118.

4. Cakmak I, Marschner H. Enhanced superoxide radical production in root of zinc deficient plants. $\mathrm{J}$ of Experimental Botany 2003;39:449-460.

5. Cakmak I, Marschner H, Bengerth F. Effect of zinc nutritional status on growth, protein metabolism and levels of indole-acetic and other phytochromes in bean (Phaseolus vulgaris L.). Journal of Experimental Botany 1998;4:405-412.

6. Dwivedi, Neeta, Mishra PH. Effect of zinc and iron on chlorophyll and enzymatic activities in wheat varieties. Indian J Plant Physiol 1997;2(3):255-256.

7. Mishra PH, Mehrotra ON. Physiological studies on differential uptake of nitrogen and zinc by wheat varieties growth and yield aspects. Form Science Journal 2006;1(1-2):26-32.

8. Singh AK, Dubey RS. Changes in chlorophyll a and b contents and activities of photosynthesis 1 and 2 in rice seedlings induced by $\mathrm{NaCl}$. Photosynthitics 2005;31(4):489-499. 35 ref.

9. Verma HR, Prakash O. Physiological performance of wheat varieties in respect of $\mathrm{N}$ and $\mathrm{Zn}$ application under irrigated situation. Abstract $2^{\text {nd }}$ International Congress of Plant Physiology. Jan. 8-12, New Delhi $\left(\mathrm{S}_{4}-\mathrm{P}_{102}\right)$ 2003, 209.

10. Wang P, Zhou DM, Lou XS, Li LZ. Effect of zinccomplex on zinc uptake by wheat (Triticum aestivum L.) roots: A comprehensive consideration of physical chemical and biological process on biouptake, Plant and Soil 2009;316(1-2):177-192. 